\title{
合成高分子ナノ粒子による標的分子の吸着と中和
}

\author{
小出裕之
}

\section{Design of Synthetic Polymer Nanoparticles That Capture and Neutralize Target Molecules}

\author{
Hiroyuki Koide \\ Department of Medical Biochemistry, School of Pharmaceutical Sciences, University of \\ Shizuoka; 52-1 Yada, Suruga-ku, Shizuoka 422-8526, Japan.
}

(Received May 27, 2021)

\begin{abstract}
Protein affinity reagents that specifically and strongly bind to target molecules are widely used in disease detection, diagnosis, and therapy. Although antibodies and their fragments are the gold standard in protein-protein inhibitors (PPIs), synthetic polymers such as linear polymers, dendrimers, and nanoparticles as cost-effective PPIs have attracted great attention as alternatives to antibodies. These polymers exhibit high affinity to the target by imitating natural protein-protein interactions. However, only a few in vivo applications have been reported. Here, our recent advances in the development of synthetic polymers for in vivo application are reviewed. Poly $(N$-isopropylacrylamide) (pNIPAm) was used as a model of synthetic affinity reagents. Incorporation of both sulfated carbohydrate and hydrophobic monomers into lightly crosslinked pNIPAm nanoparticles (NPs) captured and neutralized vascular endothelial growth factor (VEGF) and inhibited tumor growth upon intravenous injection into tumor-bearing mice. Modification of a liposome with the pNIPAm-based linear polymer increased the polymer circulation time after intravenous injection and improved the affinity for the target. The pNIPAm-based NPs delivered by oral administration captured the target small molecules and inhibited their absorption from the intestine. Our recent findings provide useful information for the design of synthetic polymers that capture target molecules in vivo.
\end{abstract}

Key words_ _ polymer nanoparticle; molecular recognition; protein affinity reagent; lipid nanoparticle; linear polymer

\section{1.はじめに}

標的分子に対して高い親和性と特異性を兼ね備え ている材料は，検出試薬や診断薬に限らず，近年特 に治療薬としての利用が飛躍的に進んでいる. 現 在，抗体やそのフラグメントがその中心的な役割を 担っており，1）これまでに多くの抗体医薬品が臨床 で用いられている。 今尚多くの抗体医薬品の臨床試 験が進められていることから，今後も抗体医薬品が 医薬品開発の主流になっていくことは容易に想像で きる.しかしながら，抗体医薬品の開発には莫大な 費用が必要とされていることも周知の事実であり, 医療費削減が課題となつている昨今ではその改善が 必要とされている。 また，抗体医薬品は生体由来の 医薬品であることから，長期間の安定性や再現性が

静岡県立大学薬学部医薬生命化学教室（干422-8526 静 岡市駿河区谷田 52-1)

e-mail: hkoide@u-shizuoka-ken.ac.jp

本総説は, 2020 年度日本薬学会東海支部学術奨励賞の

受賞を記念して記述したものである.
課題として挙げられている，そのため，抗体に代わ る安価で安定性の高い新規材料開発が望まれている.

近年，直鎖高分子やデンドリマー，ナノ粒子など の合成高分子材料が標的分子に対して高い親和性と 特異性を有する材料として注目されている。 そもそ もタンパク質間の特異的で強い結合は静電的相互作 用や疎水性相互作用などの弱い非共有結合の多点結 合により形成されている．合成高分子はこの自然界 のタンパク質間相互作用を模倣し，これら非共有結 合を生み出す官能基をその表面に露出させること で，抗体様の親和性と特異性の獲得を可能としてい る. 2) 例えば， $N$-isopropylacrylamide（NIPAm）を 基盤とする直鎖ポリマーに，負電荷モノマーである アクリル酸（AAc）や疎水性モノマーである $N$ tert-butylacrylamide（TBAm）を付与することでミ ツバチの毒素であるメリチンペプチドに強く結合す ることが可能となる. ${ }^{3)}$ この直鎖ポリマーは，モノ マー組成だけでなくその鎖長を最適化することで特 異性が飛躍的に向上することも報告されている. ${ }^{4)}$ 
デンドリマーは，その表面に硫酸基を露出させるこ とで，セレクチンに高い親和性を示す．5) また，糖 鎖高分子にマンノースを修飾することで, dendritic cell-specific ICAM-3 grabbing non-integrin (DCSIGN）に高い親和性を獲得することが可能であ る. ${ }^{6)}$ ナノ粒子については, $N, N^{\prime}$-Methylenebis (acrylamide)（Bis）にて架橋した poly NIPAm ナ ノ粒子に至適量の電荷モノマーや疎水性モノマーを 組み込むことで, $\operatorname{IgG},{ }^{7)}$ ヘビ毒, ${ }^{8)}$ リポ多糖9)に高 い親和性を示すことが報告されている. ${ }^{10)}$ 本稿で は，筆者らが開発してきた生体内で標的分子を吸着 して中和するナノ粒子開発について概説する.

\section{2. 生体内で血管内皮細胞増殖因子（vascular en-} dothelial growth factor; VEGF) を吸着・中和する ナノ粒子開発とがん治療応用

正常組織は既存の血管から十分な酸素や栄養素を 得ている. しかし，がんは正常組織と比較して増殖 速度が早いだけでなく無限に増殖することから，成 長するにつれて既存の血管からでは，その増殖速度 に追いつくだけの酸素や栄養素の獲得が難しくな

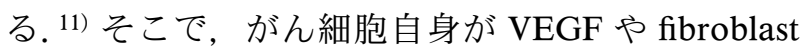
growth factor (FGF), platelet-derived growth factor （PDGF）などの増殖因子を産生し，その周辺に新 生血管を構築する. ${ }^{11)}$ 固形がんの成長は新生血管か らの栄養素獲得に依存しているため, 新生血管を破 綻することは栄養素の供給遮断によるがんの増殖阻

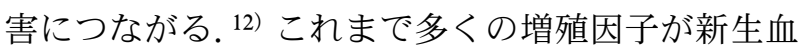
管の構築には関与していると報告されているが, VEGF はより密接に血管新生に関与している. ${ }^{13)}$ そ のため，VEGFを中和する抗体やアプタマーだけ でなく，その受容体のリン酸化を阻害する低分子薬 が開発若しくは臨床試験に進んでいる。特に抗 VEGF 抗体は医薬品開発において魅力的な夕ー ゲットである. ${ }^{14)}$

VEGF を吸着するナノ粒子開発にあたり，VEGF がその受容体との結合ドメインのほかに，ヘパリン との結合ドメインを有していることに着目した. VEGF は生体内での構造安定化や，受容体との親 和性を向上させるためにへパリンやへパラン硫酸と の結合ドメインを保持している. ${ }^{15,16)}$ ヘパリンは硫 酸化された糖鎖高分子であることから，Maynard and Hubbell はペプチドを硫酸化することで, VEGF との相互作用が増強すると報告している. ${ }^{17)}$
そこで，ナノ粒子にヘパリン類似モノマーを組み込 むことで VEGF と高い相互作用を有するナノ粒子 開発が可能となるのではないかと考えた。また， VEGF の機能を阻害するためには，ヘパリン結合 ドメインのほかに受容体結合ドメインを塞ぐ必要が ある。これまでに，VEGF-VEGF 受容体間の結合 には，多数の疎水性相互作用が関与していると報告 されている. ${ }^{18)}$ そこで，NIPAm，架橋剤である Bis に加えて，ヘパリン類似モノマーである 3,4,6 trisulfate- $N$-acetylglucosamine $(3,4,6 \mathrm{~S})$, 疎水性モ ノマーである TBAm を用いて, ラジカル重合反応 によりナノ粒子合成を行った [Fig. 1(A)]。合成し たナノ粒子と VEGF との相互作用を quartz crystal microbalance (QCM) により解析したところ，へパ リン類似モノマー $(3,4,6 \mathrm{~S})$ と疎水性モノマーの組 み込み量は VEGF との相互作用に大きく影響する ことが明らかになった。特にへパリン類似モノマー である 3,4,6S は総モノマー量に対して $1.7 \%$ と少量 組み込むことで VEGF に対して高い相互作用を示 した [Fig. 1(B)]. ${ }^{19)}$ VEGF は，中性〜弱塩基性の タンパク質であるため, その構造内には正電荷と疎 水性アミノ酸のほかに多数の負電荷アミノ酸が含ま れている。 そのため, ヘパリン類似モノマーである 3,4,6S の過剩な組み込みは, 負電荷アミノ酸と静電 的反発を引き起こした可能性がある。.また組成を最 適化したナノ粒子は，ヘパリン結合ドメインを欠損 したVEGF $\left(\mathrm{VEGF}_{121}\right)$ に対してはほとんど相互作 用しなかったことから，ナノ粒子は，VEGF のへ パリン結合ドメインを選択的に認識して結合してい ることが示唆された [Fig. 1(C)].

この最適化したナノ粒子のインビトロにおける VEGF 阻害効果を, ヒト臍帯静脈内皮細胞（human umbilical vein endothelial cell; HUVEC) を用 いて検討したところ，ナノ粒子は VEGF 依存的な HUVEC の増殖及び受容体のリン酸化，管腔形成を 抑制することが明らかになった。これは，ナノ粒子 がヘパリン結合ドメインを介して VEGF に結合し た後に TBAm が受容体との結合ドメインに作用し, VEGF と受容体との相互作用を阻害したと考えら れる。次に，ナノ粒子のインビボでの VEGF 阻害 効果の検証を，担がんマウスを用いた腫瘍増殖抑制 試験にて行った。がん細胞を皮下移植した担がんモ デルマウスにナノ粒子を静脈内投与すると，その投 
(A)

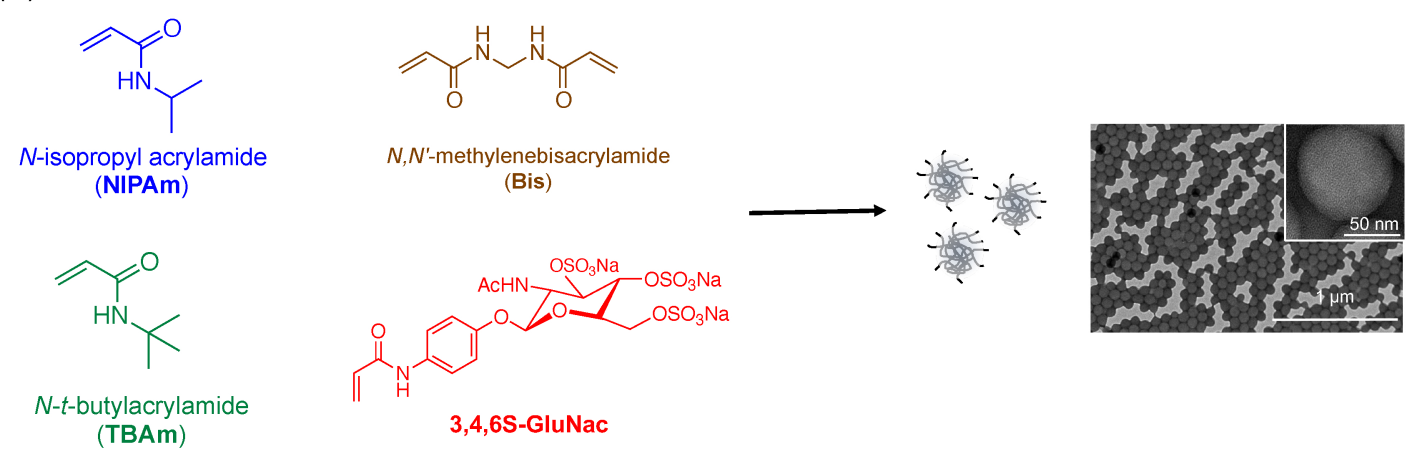

(B)

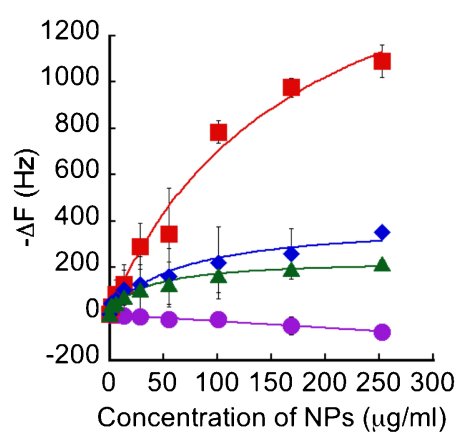

(C)

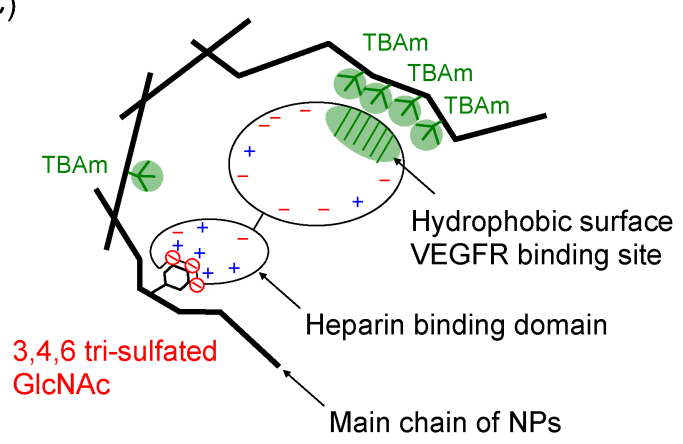

Fig. 1. Design of NPs with High VEGF Affinity

(A) Functional monomers used to prepare NPs and transmission electron microscope (TEM) image of NPs. (B) Affinity of NPs for VEGF. QCM sensor cells were functionalized with VEGF and blocked with bovine serum albumin. NPs were then added and the binding amount (frequency change) was monitored. Red; $1.7 \% 3,4,6 \mathrm{~S} \mathrm{NPs}$, blue; $5 \%$ 3,4,6S NPs, green; $10 \% 3,4,6 \mathrm{~S} \mathrm{NPs}$, purple; $0 \% 3,4,6 \mathrm{~S} \mathrm{NPs}$. (C) Schematic image of NP and VEGF interaction. Reproduced from Nat. Chem., 9 (7), 715-722 (2017). (Color figure can be accessed in the online version.)

与量依存的に腫瘍の増殖を抑制した $\left[\right.$ Fig. 2(A) ]. ${ }^{20)}$ また，抗 VEGF 抗体である Avastin は，臨床では 抗がん剂と併用されている。がん細胞は常に VEGF を産生しているため, 腫瘍周辺には無数の

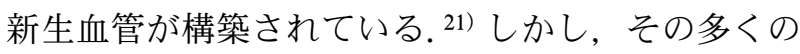
新生血管は脆弱で血流が通つていないことから, 腫 瘍は低酸素状態にあり，静脈内に投与された抗がん 剤の腫瘍への送達量は, 腫瘍周辺の血管量にかなら ずしも比例しない. ${ }^{21)}$ VEGF 阻害剤を投与すると, 腫瘍血管が壁細胞で覆われた構造に normalize（正 常化）し，低酸素状態が改善するだけでなく腫瘍へ の抗がん剂の送達量を増強する作用があるとの報告 がある. ${ }^{22,23)}$ そこで，ナノ粒子と抗がん剂であるド キソルビシンを腫瘍移植モデルマウスに併用投与し たところ, 腫瘍中の血管数が減少するだけでなく, ドキソルビシン単剤で投与するよりもナノ粒子と併 用投与することで腫瘍へのドキソルビシン送達量が 有意に上昇し，より高い抗腫瘍効果を示した $[\mathrm{Fig}$. 2(B) ]. 以上より，ヘパリン類似モノマーと疎水性 モノマーを組み込んだナノ粒子のがん治療への有用
性が示された.

\section{3. 直鎖ポリマーの脂質ナノ粒子への修飾}

これまで標的分子に高い親和性を有する合成高分 子に関する研究が多数報告されているが, 生体内に おいてその性能を報告した例は少ない。 その理由の 1 つとして, 合成高分子の生体適合性の低さが挙げ られる. 合成高分子を静脈内に投与すると速やかに 血液中から排除され, 肝臓などの臟器に蓄積してし まう. ${ }^{24,25)}$ そのため, 浸透圧ポンプを用いた持続的 な注入を行った研究報告もある. ${ }^{26)}$ リポソームや高 分子ミセルなどの薬剤運搬体の血中滞留性を向上さ せる手段としては，ポリエチレングリコール (polyethylene glycol; PEG) にて被覆する手法が一 般的であるが, PEG は粒子表面に親水層を形成さ せることでタンパク質吸着を阻害するため, ${ }^{27)}$ 標的 分子を吸着しなければならない合成高分子には不向 きである. そこで，標的分子を生体内で持続的に吸 着可能な材料開発を行うため, 筆者らはこれまでの ようなナノ粒子ではなく，直鎖ポリマーを合成し， 生体適合性の高いリポソームに修飾することを考え 
(A)

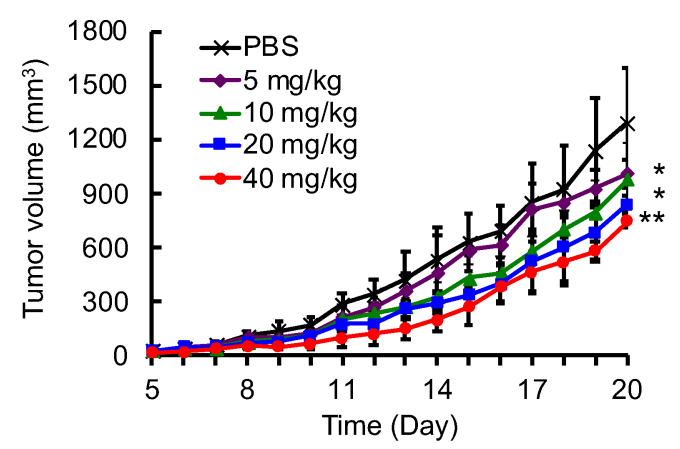

(B)

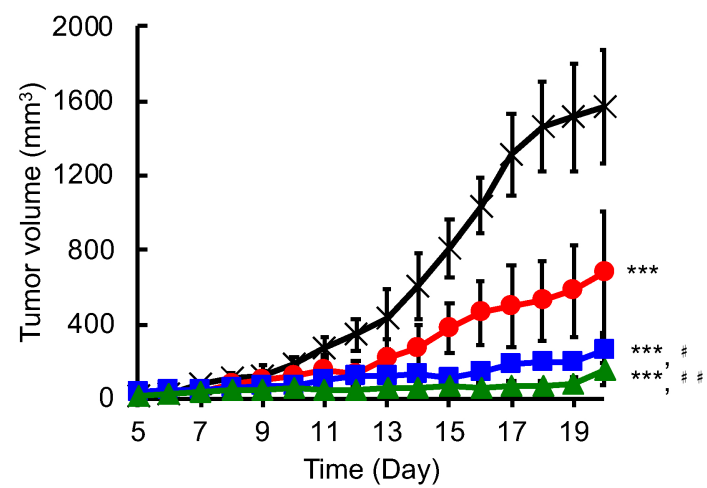

Fig. 2. Anti-tumor Effect of NPs in Vivo

(A) Anti-tumor effect of NPs. Tumor-bearing mice were intravenously injected with PBS (control) or NPs $(5,10,20$, or $40 \mathrm{mg} / \mathrm{kg}$ ) at $5,7,9$, and $11 \mathrm{~d}$ after tumor implantation. Significant difference: ${ }^{*} p<0.05$; control (PBS) vs. 10 or $20 \mathrm{mg} / \mathrm{kg},{ }^{* *} p<0.01$; control (PBS) vs. $40 \mathrm{mg} / \mathrm{kg}$. (B) Anti-tumor effect of NPs and doxorubicin. Tumor-bearing mice were intravenously injected with PBS (black), doxorubicin alone (red), combination of NPs $(20 \mathrm{mg} / \mathrm{kg})$ and doxorubicin $(5 \mathrm{mg} / \mathrm{kg}$, blue), or combination of NPs $(40 \mathrm{mg} / \mathrm{kg})$ and doxorubicin $(5 \mathrm{mg} / \mathrm{kg}$, green). NP injection was performed at day $5,7,9$, and 11 while doxorubicin injection was performed at day $6,8,10$ and 12 after tumor inoculation. Significant differences: ${ }^{* *} p$ $<0.01$; vs. PBS, ${ }^{*} p<0.05$; vs. Dox alone and ${ }^{\sharp} p<0.01 ; v s$. Dox alone. Reproduced from J. Control. Release, 295, 13-20 (2019), with permission. (Color figure can be accessed in the online version.)

た。直鎖ポリマーは架橋剤である Bis を用いず, NIPAm, TBAm, AAc を用いて鎖長が 30, 100, 1000 mer となるように可逆的付加-開裂連鎖移動型 のリビングラジカル重合により合成した $[$ Fig. 3 (A) ]. 合成した直鎖ポリマーをリポソーム表面に 修飾したところ [Fig. 3(B)]，組成と鎖長を最適化 することで標的タンパク質であるヒストンの吸着・ 中和能を示した. ${ }^{28)}$ また，直鎖ポリマーはリポソー ムの表面に修飾することで，ヒストンに対する $50 \%$ 阻害濃度（ $\mathrm{IC}_{50}$ ）が劇的に減少した [Fig. 4 (A) ].リポソーム膜を構成している脂質は自由度 が高いため，その表面を縦横無尽に移動している. そのため，表面に修飾した直鎖ポリマー 1 分子が標 的分子に結合すると，その近傍に存在する直鎖ポリ マーも結合するようになる。この協同的な結合が
$\mathrm{IC}_{50}$ の顕著な減少の 1 つの要因として考えられ る.一方，直鎖ポリマー単体では，溶液中に均一に 分散しているため標的分子に協同的に結合する可能 性は小さい.

調製したポリマー修飾リポソームの血中滞留性を 検証するため， ${ }^{3} \mathrm{H}$ にて放射標識した NIPAm を少 量組み込んで放射標識直鎖ポリマーを合成し，マウ スに静脈内投与した。すると，直鎖ポリマーのみを 投与した場合は 3 時間後に大部分が血液中から消失 していたのに対して，リポソームに修飾することで 血中残存量が顕著に上昇していた。ささらにポリ マー修飾リポソームのインビボでの標的分子吸着能 を検討するために, 致死量のヒストンを静脈内投与 した後にポリマー修飾リポソームを静脈内投与し た。その結果，直鎖ポリマーのみではヒストンによ るマウスの致死率を改善できなかつたが，ポリマー 修飾リポソームを投与することで，その致死率は大 幅に改善された [Fig. 4(B)]。これらの結果は，標 的分子を吸着・中和する合成高分子のリポソーム修 飾が，合成高分子の生体応用に向けて有用な戦略で あると示唆している。近年リポソームなど脂質ナノ 粒子を用いた標的分子吸着剂開発に関する研究が盛 んに行われており, 29-32) 本研究が有益な情報になる ことを望む.

4. 経口投与により消化管で標的分子を吸着 ·排 泄するナノ粒子開発

これまで筆者らは血液中で標的分子を吸着・中和 するナノ粒子開発を進めてきた。しかし，合成高分 子ナノ粒子の非分解性を考慮すると，消化管で標的 分子を吸着し，そのまま体外へ排泄させる役割の方 が合成高分子の特性を最大限に発揮できると考え た．本研究では標的分子のモデルとして，低分子で あるインドールを選択した，インドールは，食物中 のトリプトファンから消化管に存在する腸内細菌に よって合成された後に消化管から体内に吸収され る. ${ }^{33,34)}$ その後, 肝臓においてインドキシル硫酸に 代謝され腎臓から速やかに排泄される。しかし，腎 機能が低下した場合ではインドキシル硫酸が腎臓に 蓄積し, 活性酸素種などの産生により末期の腎不全 となってしまう. ${ }^{35)}$ そのため, 腎機能の低下を防ぐ には，インドールの消化管吸収を阻害する必要があ る.

筆者らはインドールが疎水性の高い芳香族化合物 
(A)

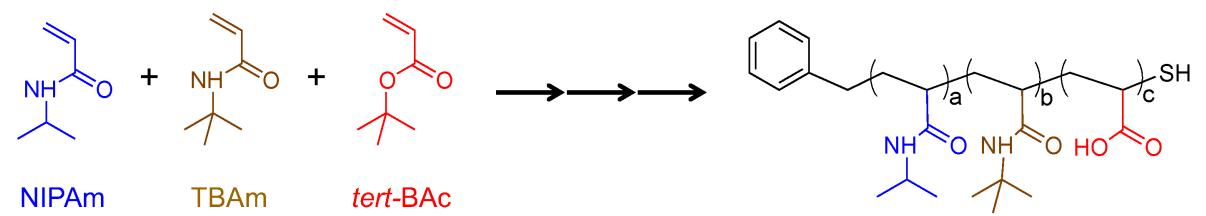

(B)

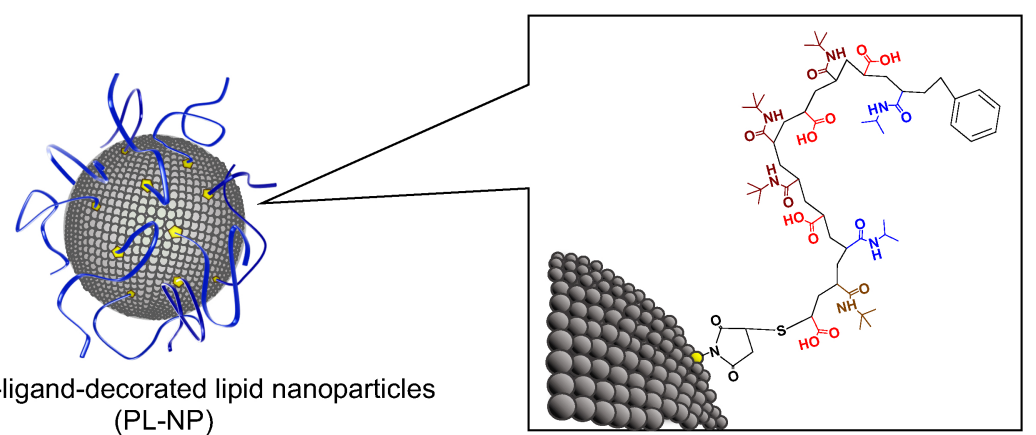

Fig. 3. Preparation of Linear Polymer-decorated Liposome

(A) Functional monomers for preparation of linear polymer, and linear polymer synthesis. Tert-BAC: tert-butyl acrylate; (B) schematic image of linear polymer-decorated liposome. Reproduced from J. Control. Release, 268, 335-342 (2017), with permission. (Color figure can be accessed in the online version.)

(A)

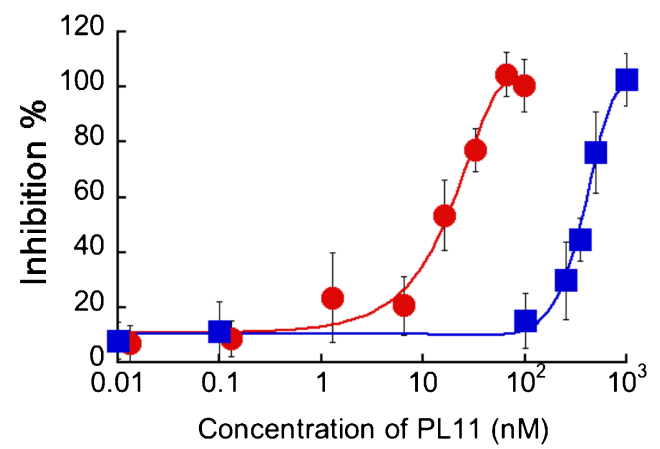

(B)

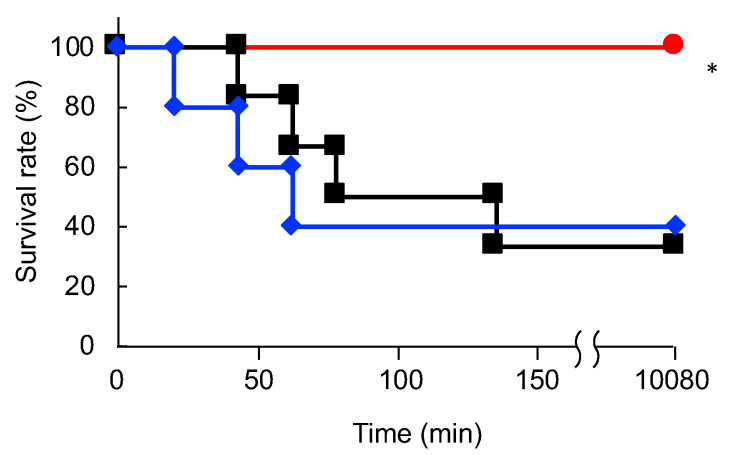

Fig. 4. Histone Neutralization by Linear Polymer-decorated Liposome

(A) Half maximal $(50 \%)$ inhibitory concentration $\left(\mathrm{IC}_{50}\right)$ of linear polymer-decorated liposome (red circle) or linear polymer alone (blue square) against histones $(45 \mu \mathrm{g} / \mathrm{mL})$. (B) Histone neutralization effect of linear polymer-decorated liposome in vivo. Mice were intravenously injected with PBS (black square), linear polymer alone ( $3 \mu \mathrm{M}$ as a PL concentration, $200 \mu \mathrm{L}$, blue diamond), or linear polymer-decorated liposome (10 mM as phospholipid concentration, $1.3 \mu \mathrm{M}$ as PL concentration, $200 \mu \mathrm{L}$ injection, red circle) at $20 \mathrm{~s}$ after intravenous histone injection $(55 \mathrm{mg} / \mathrm{kg})$. The survival rate was subsequently monitored. Significant difference: ${ }^{*} p<0.05 v s$. histone alone or linear polymer alone. Reproduced from J. Control. Release, 268, 335-342 (2017), with permission. (Color figure can be accessed in the online version.)

であることから，ナノ粒子に組み込む疎水性化合物 の構造と配合比が重要であると考えた。そこでナノ 粒子は, NIPAm, Bis に加え疎水性モノマーとして,

TBAm, $N$-phenyacrylamide (PAA), 2,3,4,5,6-pentafluorophenyl acrylamide（5FPAA）を用いて合成 した [Fig. 5(A)]。ナノ粒子によるインドール吸着 量を検証すると，疎水性モノマーの組み込み量を増 加させることでインドール吸着量も増加した。また
疎水性モノマー間で比較すると，インドール吸着量 は，PAA $<$ TBAm $<$ FFPAA となった。それぞれ の疎水性モノマー含有ナノ粒子によるインドールの 吸着様式を考えると，TBAm は粒子内で踈水性領 域を作り，インドールが疎水性相互作用でその領域 に収まっていることが考えられる。しかし PAA 含 有ナノ粒子は，インドールと $\pi-\pi$ 相互作用, $5 \mathrm{FPAA}$ 含有ナノ粒子は， $\pi-\pi$ 相互作用の中でも四 
(A)

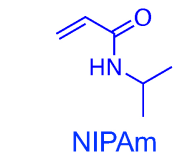

(Based monomer)<smiles>C=CC(=O)NCNC(=O)C=C</smiles>

Bis

(Cross-linker)

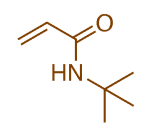

TBAm

(Hydrophobic monomer)<smiles>C=CC(=O)Nc1ccccc1</smiles>

PAA

(Hydrophobic monomer)<smiles>C=CC(=O)O</smiles>

$\mathrm{AAc}$

(Negatively charged monomer)<smiles>C=CC(=O)NCCCN</smiles>

APM

(Positively charged monomer)<smiles>C=CC(=O)Nc1c(F)c(F)c(F)c(F)c1F</smiles>

5FPAA

(Hydrophobic monomer)

(B)

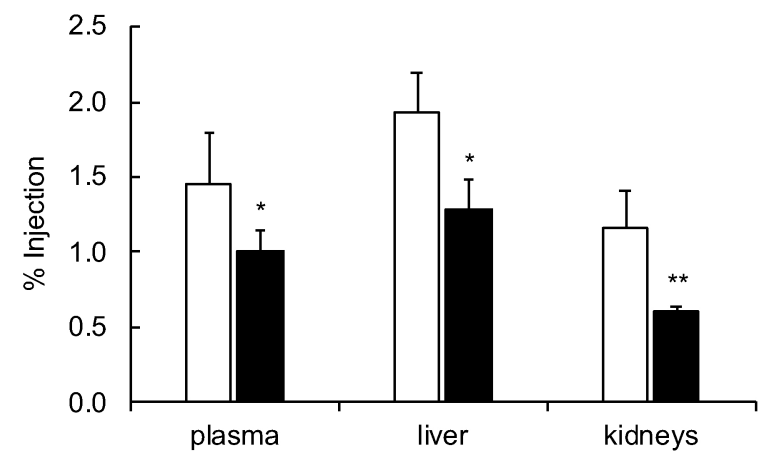

Fig. 5. Indole Capture by NPs

(A) Functional monomers for the preparation of NPs with high indole affinity. (B) Inhibition of indole absorption by NPs. $\left[{ }^{14} \mathrm{C}\right]-$ labeled indole $(43 \mathrm{nmol} /$ mouse) and/or NPs ( $5 \mathrm{mg} /$ mouse) were orally injected into mice. One hour after the injection, radioactivity in plasma, liver, and kidneys was measured. Open bar $\left[{ }^{14} \mathrm{C}\right]$-labeled indole alone injection, black bar; $\left[{ }^{14} \mathrm{C}\right]$-labeled indole and NPs injection. Significant difference: ${ }^{*} p<0.05$ and ${ }^{* *} p<0.01 v s$. indole alone injection. Reproduced from Biomacromolecules, 20 (4), 1644-1654 (2019), with permission. (Color figure can be accessed in the online version.)

極子相互作用により結合していると考えられる．そ のため, 2 種類の踈水性モノマー (TBAm, 5FPAA) を組み込んだナノ粒子を合成した結果，1 種類の疎 水性モノマー含有ナノ粒子よりも高いインドール吸 着能を示した。合成したナノ粒子のインビボでのイ ンドール吸収阻害効果を検討したところ，ナノ粒子 を用いることでインドールの消化管吸収を顕著に阻 害した [Fig. 5(B)]．以上より，機能性モノマーの 構造とその組成を最適化することで低分子化合物の 消化管吸収を阻害可能であることが示唆された。 ${ }^{36)}$

\section{5. おわりに}

本稿では，生体内で標的分子を吸着するナノ粒子 開発について紹介した．合成高分子は，導入する材 料を変えることで様々な機能を付与することができ る。しかし，生体内でその機能を実現した例は少な い。それゆえ，安全性に関する情報はまだまだ少な
い. 今後更なる研究が進み, 生体内で機能を発揮す る安全性の高い合成高分子開発が進むことを望む.

謝辞最後になりましたが，本研究の遂行にあ たりご指導ご鞭撻を賜りました静岡県立大学薬学部 浅井知浩教授, 帝京大学薬学部教授 奥 直人教 授, 浜松医科大学光尖端医学教育研究センター 清 水広介准教授に心から感謝申し上げます．多くの御 助言, ご指導賜りましたカリフォルニア大学化学科 Kenneth J. Shea 教授, 九州大学工学研究院 三浦佳 子教授，星野 友准教授に深謝いたします。また， 静岡県立大学薬学部医薬生命化学教室の学生の方々 に厚く御礼申しあげます。本研究は日本学術振興会 科学研究費補助金（研究活動スタート支援： 26888014 , 若手研究 B: 7K14519, 基盤研究 B: 19H04450）の助成を受けて実施したものであり, 
ここに感謝申し上げます。

利益相反 開示すべき利益相反はない.

\section{REFERENCES}

1) Hardiman G., Proc. Natl. Acad. Sci. USA, 109, 18245-18246 (2012).

2) Mahon C. S., Fulton D. A., Nat. Chem., 6, 665-672 (2014).

3) Wada Y., Lee H., Hoshino Y., Kotani S., Shea K. J., Miura Y., J. Mater. Chem. B, 3, 1706-1711 (2015).

4) Lee H., Hoshino Y., Wada Y., Arata Y., Maruyama A., Miura Y., J. Am. Chem. Soc., 137, 10878-10881 (2015).

5) Dernedde J., Rausch A., Weinhart M., Enders S., Tauber R., Licha K., Schirner M., Zügel U., von Bonin A., Haag R., Proc. Natl. Acad. Sci. USA, 107, 19679-19684 (2010) .

6) Zhang Q., Collins J., Anastasaki A., Wallis R., Mitchell D. A., Becer C. R., Haddleton D. M., Angew. Chem. Int. Ed., 52, 4435-4439 (2013).

7) Lee S. H., Hoshino Y., Randall A., Zeng Z., Baldi P., Doong R. A., Shea K. J., J. Am. Chem. Soc., 134, 15765-15772 (2012).

8) O'Brien J., Lee S. H., Onogi S., Shea K. J., J. Am. Chem. Soc., 138, 16604-16607 (2016) .

9) Chou B., Mirau P., Jiang T., Wang S. W., Shea K. J., Biomacromolecules, 17, 1860-1868 (2016).

10) Weisman A., Chou B., O’Brien J., Shea K. J., Adv. Drug Deliver. Rev., 90, 81-100 (2015).

11) Nishida N., Yano H., Nishida T., Kamura T., Kojiro M., Vasc. Health Risk Manag., 2, 213219 (2006).

12) Vasudev N. S., Reynolds A. R., Angiogenesis, 17, 471-494 (2014).

13) Carmeliet P., Oncology., 69, 4-10 (2005).

14) Garcia J., Hurwitz H. I., Sandler A. B., Miles D., Coleman R. L., Deurloo R., Chinot O. L., Cancer Treat. Rev., 86, 102017 (2020).

15) Xu D., Fuster M. M., Lawrence R., Esko J. D., J. Biol. Chem., 286, 737-745 (2011).

16) Iozzo R. V., San Antonio J. D., J. Clin. Invest., 108, 349-355 (2001).

17) Maynard H. D., Hubbell J. A., Acta Biomater., 1, 451-459 (2005).
18） Brozzo M. S., Bjelić S., Kisko K., Schleier T., Leppänen V. M., Alitalo K., Winkler F. K., Ballmer-Hofer K., Blood, 119, 1781-1788 (2012).

19) Koide H., Yoshimatsu K., Hoshino Y., Lee S. H., Okajima A., Ariizumi S., Narita Y., Yonamine Y., Weisman A. C., Nishimura Y., Oku N., Miura Y., Shea K. J., Nat. Chem., 9, 715-722 (2017).

20) Koide H., Yoshimatsu K., Hoshino Y., Ariizumi S., Okishima A., Ide T., Egami H., Hamashima Y., Nishimura Y., Kanazawa H., Miura Y., Asai T., Oku N., Shea K. J., J. Control. Release, 295, 13-20 (2019).

21) Noguera-Troise I., Daly C., Papadopoulos N. J., Coetzee S., Boland P., Gale N. W., Lin H. C., Yancopoulos G. D., Thurston G., Nature, 444, 1032-1037 (2006).

22) Carmeliet P., Jain R. K., Nat. Rev. Drug Discov., 10, 417-427 (2011).

23) Wildiers H., Guetens G., De Boeck G., Verbeken E., Landuyt B., Landuyt W., de Bruijn E. A., van Oosterom A. T., Br. J. Cancer, $\mathbf{8 8 ,}$ 1979-1986 (2003).

24) Hoshino Y., Koide H., Furuya K., Haberaecker W. W. 3rd, Lee S. H., Kodama T., Kanazawa H., Oku N., Shea K. J., Proc. Natl. Acad. Sci. USA, 109, 33-38 (2012).

25) Koide H., Yoshimatsu K., Hoshino Y., Ariizumi S., Okishima A., Ide T., Egami H., Hamashima Y., Nishimura Y., Kanazawa H., Miura Y., Asai T., Oku N., Shea K. J., J. Control. Release, 295, 13-20 (2019).

26) De León-Rodríguez L. M., Lubag A., Udugamasooriya D. G., Proneth B., Brekken R. A., Sun X., Kodadek T., Dean Sherry A., J. Am. Chem. Soc., 132, 12829-12831 (2010).

27) Michel R., Pasche S., Textor M., Castner D. G., Langmuir, 21, 12327-12332 (2005) .

28) Koide H., Tsuchida H., Nakamoto M., Okishima A., Ariizumi S., Kiyokawa C., Asai T., Hoshino Y., Oku N., J. Control. Release, 268, 335-342 (2017).

29) Koide H., Hirano S., Ide T., Saito K., Suzuki H., Yasuno G., Hamashima Y., Yonezawa S., Oku N., Asai T., Adv. Funct. Mater., 2005641 (2020).

30) Hu C. M., Fang R. H., Copp J., Luk B. T., Zhang L., Nat. Nanotechnol., 8, 336-340 
(2013) .

31) Fang R. H., Luk B. T., Hu C. M., Zhang L., Adv. Drug Deliv. Rev., 90, 69-80 (2015) .

32) Koide H., Suzuki H., Ochiai H., Egami H., Hamashima Y., Oku N., Asai T., Biochem. Biophys. Res. Commun., 555, 32-39 (2021).

33) Banoglu E., King R. S., Eur. J. Drug Metab. Pharmacokinet., 27, 135-140 (2002).

34) Vanholder R., Schepers E., Pletinck A., Na- gler E. V., Glorieux G., J. Am. Soc. Nephrol., 25, 1897-1907 (2014).

35) Duranton F., Cohen G., De Smet R., Rodriguez M., Jankowski J., Vanholder R., $J$. Am. Soc. Nephrol., 24, 2127-2129 (2013).

36) Okishima A., Koide H., Hoshino Y., Egami H., Hamashima Y., Oku N., Asai T., Biomacromolecules, 20, 1644-1654 (2019). 